\title{
Construction of diverse supramolecular assemblies of dimetal subunits differing in coordinated water molecules via strong hydrogen bonding interactions: Synthesis, crystal structures and spectroscopic properties
}

\author{
SADHIKA KHULLAR ${ }^{\mathrm{a}, \mathrm{b}}$ and SANJAY K MANDAL ${ }^{\mathrm{a}, *}$ \\ a Department of Chemical Sciences, Indian Institute of Science Education and Research, Mohali, Sector 81, \\ Manauli PO, S.A.S. Nagar, Mohali (Punjab) 140 306, India \\ ${ }^{b}$ Department of Chemistry, DAV University, Jalandhar, Punjab 144 001, India \\ e-mail: sanjaymandal@iisermohali.ac.in
}

MS received 3 May 2014; revised 27 June 2014; accepted 29 June 2014

\begin{abstract}
Three new supramolecular assemblies (constructed through strong hydrogen bonding) of $\left.\left[\mathrm{Co}_{2} \text { (bpta) }\right)_{2}(\mathrm{adc})\left(\mathrm{H}_{2} \mathrm{O}\right)_{4}\right]\left(\mathrm{ClO}_{4}\right)_{2} 2 \mathrm{H}_{2} \mathrm{O}(\mathbf{1}),\left[\mathrm{Cu}_{2}(\text { bpta })_{2}(\mathrm{fum})\left(\mathrm{H}_{2} \mathrm{O}\right)_{2}\right]\left(\mathrm{ClO}_{4}\right)_{2}(\mathbf{2})$ and $\left[\mathrm{Cu}_{2}(\text { bpta })_{2}(\mathrm{tdc})\left(\mathrm{H}_{2} \mathrm{O}\right)\right.$ $\left.\left(\mathrm{ClO}_{4}\right)\right]\left(\mathrm{ClO}_{4}\right) \cdot 3 \mathrm{H}_{2} \mathrm{O}(3)$, which are synthesised by one pot self-assembly of the metal salt, bpta ligand and the corresponding dicarboxylate under the same reaction conditions, are reported (where adc $=$ acetylene dicarboxylate, fum $=$ fumarate, $\operatorname{tdc}=2,5$-thiophenedicarboxylate and bpta $=\mathrm{N}, \mathrm{N}^{\prime}$-bis(2-pyridylmethyl)-tertbutylamine). These compounds have varying degrees of coordinated water molecules per dimetal subunits (four for $\mathbf{1}$, two for $\mathbf{2}$ and one for $\mathbf{3}$, respectively). Furthermore, the orientation of the coordinated water molecules in $\mathbf{1}$ and 2, with respect to the mono (carboxylato)-bridged dimetal subunit, is different (cis and trans, respectively). On the other hand, there is a coordinated perchlorate ion in $\mathbf{3}$ making the two metal centers inequivalent. Unlike $\mathbf{1}$ and $\mathbf{3}$, there are no lattice water molecules in $\mathbf{2}$. This difference in the dimetal subunit in $\mathbf{1 - 3}$ and the presence or absence of the lattice water molecules are the keys to forming the diverse supramolecular assemblies. In $\mathbf{1}$ and $\mathbf{3}$, the involvement of lattice water molecules in the construction of such assemblies is distinctly different. In case of $\mathbf{2}$, the formation of supramolecular assembly depends on the coordinated water molecule (trans to each other) and thus a ladder shaped supramolecular assembly is the result. The strength of hydrogen bonding observed in the networks of $\mathbf{1}-\mathbf{3}$ is indicated in the $\mathrm{O} \cdots \mathrm{O}$ distances $(2.596 \AA$ to $3.160 \AA)$ and the O$\mathrm{H}$. . O angles $124^{\circ}$ to $176^{\circ}$. All are characterised by elemental analysis, FTIR spectroscopy and single crystal $\mathrm{X}$-ray diffraction studies.
\end{abstract}

Keywords. Supramolecular; hydrogen bonding; flexible ligand; dicarboxylates.

\section{Introduction}

The field of supramolecular chemistry has seen an exponential growth in the last few decades due to interdisciplinary interests in crystal engineering of supramolecular assemblies that are targeted for a variety of potential applications, such as catalysis, separation, sensors, gas storage, luminescent materials, ion exchange, magnetism, etc. ${ }^{1-3}$ Synthons in a coordination supramolecular assembly are held together through various interactions, such as metal-donor atom coordinate bonds, strong and/or weak hydrogen bonds, $\pi-\pi$ stacking of aromatic moieties, C-H... O interactions, etc. ${ }^{4}$ Among these various interactions, hydrogen bonding is the most important one to study for its importance in the biological systems, in understanding the structure of water, etc. The use of metal centres or metal

*For correspondence atom clusters as building blocks adds to the advantage due to different binding abilities of the metal centre. The selection of ancillary ligands and the multitopic organic linkers is crucial in making such assemblies with varied dimensionality. The role of ancillary ligands that surround and protect the metal cores leaving open sites for the linkers is of great importance in making such supramolecular assemblies. The strategy of a step-wise association of discrete synthons, such as mono- or di-nuclear metal complexes, to construct supramolecular assemblies of higher dimensions shows the hierarchical importance of the two bondings (coordination bonds and hydrogen bonds) that are orthogonal in nature.$^{5-10}$ For our interests to explore and identify the factors governing the formation of supramolecular assemblies through various interactions, a systematic study has been carried out using a flexible tridentate ancillary ligand and multitopic dicarboxylate linkers with $\mathrm{Co}(\mathrm{II})$ and $\mathrm{Cu}$ (II) as the metal centre. 
In this paper, using the tridentate ligand, bpta $=\mathrm{N}, \mathrm{N}^{\prime}$ bis(2-pyridylmethyl)-tert-butylamine, we report the formation of diverse supramolecular assemblies from the dinuclear metal complexes: $\left[\mathrm{Co}_{2}(\mathrm{bpta})_{2}(\mathrm{adc})\right.$ $\left.\left(\mathrm{H}_{2} \mathrm{O}\right)_{4}\right]\left(\mathrm{ClO}_{4}\right)_{2} \cdot 2 \mathrm{H}_{2} \mathrm{O}$ (1), $\left[\mathrm{Cu}_{2} \text { (bpta }\right)_{2}($ fum $\left.)\left(\mathrm{H}_{2} \mathrm{O}\right)_{2}\right]$ $\left(\mathrm{ClO}_{4}\right)_{2}(\mathbf{2})$ and $\left.\left[\mathrm{Cu}_{2} \text { (bpta) }\right)_{2}(\mathrm{tdc})\left(\mathrm{H}_{2} \mathrm{O}\right)\left(\mathrm{ClO}_{4}\right)\right]\left(\mathrm{ClO}_{4}\right)$. $3 \mathrm{H}_{2} \mathrm{O}(3)$, where adc $=$ acetylene dicarboxylate, fum $=$ fumarate and $\mathrm{tdc}=2,5$-thiophenedicarboxylate. The dimetal subunits in these complexes are connected through extensive hydrogen bonding network of coordinated water molecules, lattice water molecules (in case of $\mathbf{1}$ and 3) and uncoordinated oxygen atoms of the carboxylate groups. Scheme 1 shows the structure of the ligand and dicarboxylate linkers used in this study.

\section{Experimental}

\subsection{Materials and methods}

All chemicals and solvents used for synthesis were obtained from commercial sources and were used as received, without further purification. All reactions were carried out under aerobic conditions. The bpta ligand was prepared by modifying the literature procedure. ${ }^{11}$

\subsection{Physical measurements}

The ${ }^{1} \mathrm{H}$ NMR spectrum of the ligand was obtained in $\mathrm{CDCl}_{3}$ solution at $25^{\circ} \mathrm{C}$ on a Bruker ARX-400 spectrometer; chemical shifts were reported relative to the residual solvent signals. The elemental analysis $(\mathrm{C}, \mathrm{H}$, $\mathrm{N})$ was carried out using a Mettler CHNS analyzer. IR spectra were measured in the $4000-400 \mathrm{~cm}^{-1}$ range on a Perkin-Elmer Spectrum I spectrometer with samples prepared as $\mathrm{KBr}$ pellets.

Caution! In this study metal perchlorates were used without any problem but special care should be taken while handling such dangerous salts.

\subsection{General synthesis method}

In a round bottom flask (RBF) y mmol of $\mathrm{M}\left(\mathrm{ClO}_{4}\right)_{2}$ and $\mathrm{y}$ mmol of the tridentate ligand were dissolved in 1.5 to $3 \mathrm{~mL}$ of methanol while stirring. To this was added a clear solution of the disodium salt of a dicarboxylate $\left(\mathrm{Na}_{2} \mathrm{dc}\right)$ which was prepared using $\mathrm{y} / 2 \mathrm{mmol}$ of the dicarboxylic acid and y mmol of sodium hydroxide in 1 $\mathrm{mL}$ methanol and $1 \mathrm{~mL}$ to a minimum amount of water. The reaction mixture was stirred for another 3 to 4 hours at room temperature. Either a clear solution (in case of $\mathbf{1}$ and 3 ) or a solid precipitate (in case of 2) was obtained which was processed further to get the desired product.

2.3a $\quad\left[\mathrm{Co}_{2}(\mathrm{bpta})_{2}(\mathrm{adc})\left(\mathrm{H}_{2} \mathrm{O}\right)_{4}\right]\left(\mathrm{ClO}_{4}\right)_{2} 2 \mathrm{H}_{2} \mathrm{O} \quad$ (1): $\quad$ It was prepared using the sodium salt of acetylene dicarboxylic acid $\{14 \mathrm{mg}(0.125 \mathrm{mmol})$ of acetylene dicarboxylic acid and $10 \mathrm{mg}(0.25 \mathrm{mmol})$ of sodium hydroxide \}, $48 \mathrm{mg}(0.125 \mathrm{mmol})$ of $\mathrm{Co}\left(\mathrm{ClO}_{4}\right)_{2}$ in $3 \mathrm{~mL}$ methanol and $32 \mathrm{mg}(0.125 \mathrm{mmol})$ of bpta. No precipitate was obtained; the pink filtrate was evaporated to dryness. After re-dissolving the solid residue in $2 \mathrm{~mL}$ of dry methanol completely, $10 \mathrm{mg}$ of $\mathrm{KCl}$ was added and stirred for $10 \mathrm{~h}$. A white solid that appeared was removed via filtration and the filtrate was evaporated to dryness to isolate a pink solid. Yield: $39 \mathrm{mg}$ (54\%). Anal. Calcd (\%) for $\mathrm{C}_{36} \mathrm{H}_{54} \mathrm{~N}_{6} \mathrm{Co}_{2} \mathrm{Cl}_{2} \mathrm{O}_{18}$ (MW 1047.6): C, 41.27; H, 5.15; N, 8.02. Found: C, 41.62; H, 5.25; $\mathrm{N}, 8.09$. Selected FTIR peaks $\left(\mathrm{KBr}, \mathrm{cm}^{-1}\right): 3404,1567$, 1435, 1345, 1096, 764, 621.

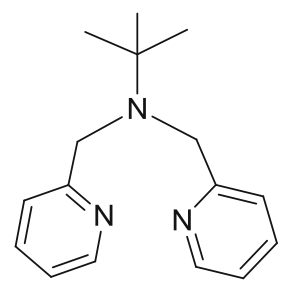

N,N-bis-(2-pyridylmethyl)-tert-butylamine (bpta)

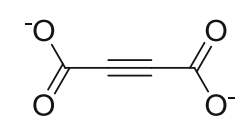

acetylene dicarboxylate<smiles>O=C([O-])/C=C/C(=O)[O-]</smiles>

fumarate

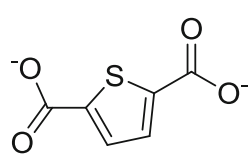

2,5-thiophene dicarboxylate

Scheme 1. Structures of the bpta ligand and the dicarboxylates. 
Table 1. Crystal structure data and refinement parameters for $\mathbf{1 , 2}$ and 3.

\begin{tabular}{|c|c|c|c|}
\hline & 1 & 2 & 3 \\
\hline Chemical formula & $\mathrm{C}_{36} \mathrm{H}_{54} \mathrm{Cl}_{2} \mathrm{Co}_{2} \mathrm{~N}_{6} \mathrm{O}_{18}$ & $\mathrm{C}_{36} \mathrm{H}_{48} \mathrm{Cl}_{2} \mathrm{Cu}_{2} \mathrm{~N}_{6} \mathrm{O}_{14}$ & $\mathrm{C}_{38} \mathrm{H}_{52} \mathrm{Cl}_{2} \mathrm{Cu}_{2} \mathrm{~N}_{6} \mathrm{O}_{16} \mathrm{~S}$ \\
\hline Formula Weight & 1047.65 & 986.78 & 1078.90 \\
\hline Temperature (K) & $296(2)$ & $296(2)$ & $296(2)$ \\
\hline Wavelength $(\AA)$ & 0.71073 & 0.71073 & 0.71073 \\
\hline Crystal system & Monoclinic & Monoclinic & Monoclinic \\
\hline Space group & $P 2_{1} / c$ & $C 2 / c$ & $P 2_{1} / n$ \\
\hline $\mathrm{a}(\AA)$ & $15.2144(15)$ & $19.9346(10)$ & $12.3812(4)$ \\
\hline b $(\AA)$ & $23.344(2)$ & $18.8069(10)$ & 26.8191(9) \\
\hline c $(\AA)$ & $26.753(3)$ & $13.6719(8)$ & $14.3028(5)$ \\
\hline$\alpha\left(^{\circ}\right)$ & 90 & 90 & 90 \\
\hline$\beta\left(^{\circ}\right)$ & $99.364(5)$ & $122.227(3)$ & $96.322(2)$ \\
\hline$\gamma\left({ }^{\circ}\right)$ & 90 & 90 & 90 \\
\hline $\mathrm{Z}$ & 8 & 4 & 4 \\
\hline Volume $\left(\AA^{3}\right)$ & $9375.1(16)$ & $4336.0(4)$ & 4720.4(3) \\
\hline Density $\left(\mathrm{g} / \mathrm{cm}^{3}\right)$ & 1.484 & 1.512 & 1.518 \\
\hline$\mu\left(\mathrm{mm}^{-1}\right)$ & 0.898 & 1.175 & 1.132 \\
\hline Theta range & $1.16^{\circ}$ to $25.14^{\circ}$ & $1.86^{\circ}$ to $25.10^{\circ}$ & $1.52^{\circ}$ to $25.10^{\circ}$ \\
\hline $\mathrm{F}(000)$ & 4352 & 2040 & 2232 \\
\hline Reflections Collected & 87093 & 12866 & 32255 \\
\hline Independent reflections & 16568 & 3863 & 8388 \\
\hline Reflections with I $>2 \sigma(\mathrm{I})$ & 7608 & 2476 & 4788 \\
\hline $\mathrm{R}_{\text {int }}$ & 0.1225 & 0.0555 & 0.0825 \\
\hline Number of parameters & 1133 & 278 & 589 \\
\hline GOF on $\mathrm{F}^{2}$ & 1.049 & 0.967 & 0.983 \\
\hline Final $\mathrm{R}_{1}^{\mathrm{a}} / \mathrm{wR}_{2}^{\mathrm{b}}(\mathrm{I}>2 \sigma(\mathrm{I}))$ & $0.0841 / 0.2216$ & $0.0536 / 0.1527$ & $0.0541 / 0.1395$ \\
\hline $\mathrm{R}_{1}^{\mathrm{a}} / \mathrm{wR}_{2}^{\mathrm{b}}$ (all data) & $0.1896 / 0.2819$ & $0.0908 / 0.1839$ & $0.1012 / 0.1589$ \\
\hline Largest diff. peak and hole $\left(\mathrm{e} \AA^{-3}\right)$ & 1.401 and -1.029 & 0.561 and -0.533 & 0.864 and -0.575 \\
\hline
\end{tabular}

${ }^{\mathrm{a}} \mathrm{R}_{1}=\Sigma\left\|\mathrm{F}_{\mathrm{o}}|-| \mathrm{F}_{\mathrm{c}}\right\| / \Sigma\left|\mathrm{F}_{\mathrm{o}}\right| \cdot{ }^{\mathrm{b}} \mathrm{wR}_{2}=\left[\Sigma \mathrm{w}\left(\mathrm{F}_{\mathrm{o}}^{2}-\mathrm{F}_{\mathrm{c}}^{2}\right)^{2} / \Sigma \mathrm{w}\left(\mathrm{F}_{\mathrm{o}}^{2}\right)^{2}\right]^{1 / 2}$, where $\mathrm{w}=1 /\left[\sigma^{2}\left(\mathrm{~F}_{\mathrm{o}}^{2}\right)+(\mathrm{aP})^{2}+\mathrm{bP}\right], \mathrm{P}=\left(\mathrm{F}_{\mathrm{o}}^{2}+2 \mathrm{~F}_{\mathrm{c}}^{2}\right) / 3$.

$2.3 b \quad\left[\mathrm{Cu}_{2}(\text { bpta })_{2}(\right.$ fum $\left.)\left(\mathrm{H}_{2} \mathrm{O}\right)_{2}\right]\left(\mathrm{ClO}_{4}\right)_{2} \quad$ (2): It was prepared using the sodium salt of fumaric acid $\{14.5$ $\mathrm{mg}(0.125 \mathrm{mmol})$ of fumaric acid and $10 \mathrm{mg}(0.25$ mmol $)$ of sodium hydroxide $\}, 46.5 \mathrm{mg}(0.125 \mathrm{mmol})$ of $\mathrm{Cu}\left(\mathrm{ClO}_{4}\right)_{2}$ in $3 \mathrm{~mL}$ methanol and $32 \mathrm{mg}(0.125 \mathrm{mmol})$ of bpta. A blue precipitate was collected via filtration, washed with methanol and air-dried. Yield: $41 \mathrm{mg}$ (69\%). Anal. Calcd (\%) for $\mathrm{C}_{36} \mathrm{H}_{48} \mathrm{~N}_{6} \mathrm{Cu}_{2} \mathrm{Cl}_{2} \mathrm{O}_{14}$ (MW 986.8): C, 44.98; H, 4.86; N, 8.57. Found: C, 45.34; $\mathrm{H}, 4.63 ; \mathrm{N}, 8.38$. Selected FTIR peaks $\left(\mathrm{KBr}, \mathrm{cm}^{-1}\right)$ : 3438, 1606, 1563, 1481, 1441, 1380, 1077, 762, 698, 619.

$$
\begin{aligned}
& \mathrm{Co}\left(\mathrm{ClO}_{4}\right)_{2}+\text { bpta } \underset{\mathrm{MeOH}, \mathrm{RT}}{\stackrel{\mathrm{Na}_{2} \mathrm{adc}}{\longrightarrow}}\left[\mathrm{Co}_{2}(\text { bpta })_{2}(\mathrm{adc})\left(\mathrm{H}_{2} \mathrm{O}\right)_{4}\right]\left(\mathrm{ClO}_{4}\right)_{2} \cdot 2 \mathrm{H}_{2} \mathrm{O}(\mathbf{1})
\end{aligned}
$$

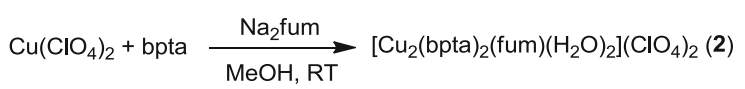

$$
\begin{aligned}
& \mathrm{Cu}\left(\mathrm{ClO}_{4}\right)_{2}+\text { bpta } \underset{\mathrm{MeOH}, \mathrm{RT}}{\stackrel{\mathrm{Na}_{2} \mathrm{tdc}}{\longrightarrow}}\left[\mathrm{Cu}_{2}(\mathrm{bpta})_{2}(\mathrm{tdc})\left(\mathrm{H}_{2} \mathrm{O}\right)\left(\mathrm{ClO}_{4}\right)\right]\left(\mathrm{ClO}_{4}\right) \cdot 3 \mathrm{H}_{2} \mathrm{O}(3)
\end{aligned}
$$

Scheme 2. Synthesis of 1-3.
$2.3 \mathrm{c} \quad\left[\mathrm{Cu}_{2}(\text { bpta })_{2}(\mathrm{tdc})\left(\mathrm{H}_{2} \mathrm{O}\right)\left(\mathrm{ClO}_{4}\right)\right]\left(\mathrm{ClO}_{4}\right) \cdot 3 \mathrm{H}_{2} \mathrm{O}(3)$ : It was prepared using the sodium salt of thiophene dicarboxylic acid $\{21.5 \mathrm{mg}(0.125 \mathrm{mmol})$ of thiophene dicarboxylic acid and $10 \mathrm{mg}(0.25 \mathrm{mmol})$ of sodium hydroxide \}, $46.5 \mathrm{mg}(0.125 \mathrm{mmol})$ of $\mathrm{Cu}\left(\mathrm{ClO}_{4}\right)_{2}$ in $3 \mathrm{~mL}$ methanol and $32 \mathrm{mg}(0.125 \mathrm{mmol})$ of bpta. No precipitate was obtained and the dark blue filtrate was evaporated to dryness. After re-dissolving the solid residue in $2 \mathrm{~mL}$ of dry methanol completely, $10 \mathrm{mg}$ of $\mathrm{KCl}$ was added and stirred for $3 \mathrm{~h}$. A white solid that appeared was filtered off and the filtrate was evaporated to dryness to isolate a dark blue solid. Yield: 64

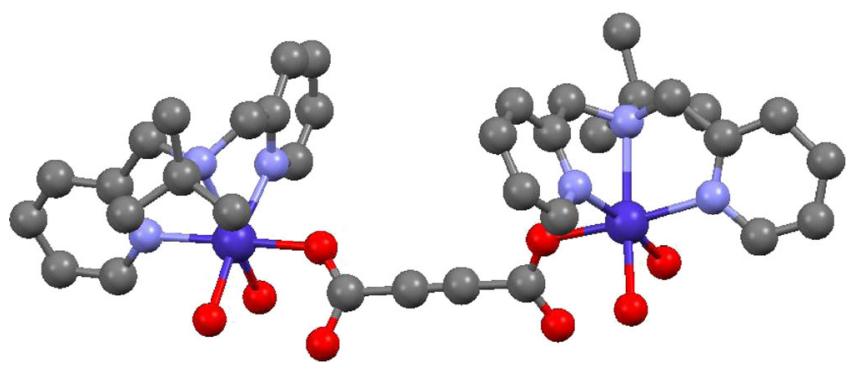

Figure 1. Structure of the dimetal subunit in $\mathbf{1}$. 
mg (98\%). Anal. Calcd (\%) for $\mathrm{C}_{38} \mathrm{H}_{50} \mathrm{~N}_{6} \mathrm{Cu}_{2} \mathrm{Cl}_{2} \mathrm{SO}_{15}$ (MW 1060.9): C, 43.02; H, 4.71; N, 7.92. Found: C, 43.36; H, 4.58; N, 7.93. Despite our best efforts, in the
CHN analysis two water molecules could be included while three water molecules were found in its X-ray crystal structure. Selected FTIR peaks $\left(\mathrm{KBr}, \mathrm{cm}^{-1}\right)$ :

Table 2. Selected bond distances and bond angles for 1, 2 and $\mathbf{3}$.

1

Bond distances $(\AA)$

Co1-O1

Co1-O3

Co1-O4

Co1-N1

Co1-N2

Co1-N3

Bond angles $\left({ }^{\circ}\right)$

N3-Co1-O1

O1-Co1-O3

$\mathrm{O} 1-\mathrm{Co} 1-\mathrm{N} 2$

N3-Co1-O4

$\mathrm{O} 3-\mathrm{Co} 1-\mathrm{O} 4$

N3-Co1-N1

O3-Co1-N1

O4-Co1-N1

N3-Co1-O3

$\mathrm{N} 3-\mathrm{Co} 1-\mathrm{N} 2$

O3-Co1-N2

O1-Co1-O4

N2-Co1-O4

O1-Co1-N1

N2-Co1-N1

2

Bond distances $(\AA)$

Cu1-N1

Cu1-N2

Cu1-N3

Bond angles $\left({ }^{\circ}\right)$

$\mathrm{O} 2-\mathrm{Cu} 1-\mathrm{N} 2$

N2-Cu1-N1

N2-Cu1-N3

O2-Cu1-O1

N1-Cu1-O1

3

Bond distances $(\AA)$

Cu1-N1

Cu1-N2

Cu1-N3

Cu1-O1

Bond angles $\left({ }^{\circ}\right)$

O1-Cu1-N1

N1-Cu1-N3

N1-Cu1-N2

O1-Cu1-N3

O1-Cu1-N2

N3-Cu1-N2

O3-Cu2-O5

N4-Cu2-O5

$\begin{array}{lll}2.106(5) & \text { Co2-O5 } & 2.119(5) \\ 2.115(6) & \text { Co2-O8 } & 2.095(5) \\ 2.144(7) & \text { Co2-O7 } & 2.120(5) \\ 2.253(6) & \text { Co2-N4 } & 2.235(6) \\ 2.121(7) & \text { Co2-N5 } & 2.095(6) \\ 2.102(6) & \text { Co2-N6 } & 2.116(6)\end{array}$

97.3(2)

91.0(2)

171.7(2)

91.6(2)

85.8(2)

163.0(2)

104.9(2)

91.7(2)

89.6(2)

89.7(2)

175.4(2)

86.0(2)

$79.5(2)$

$77.2(2)$

98.1(2)

$103.5(2)$

$78.8(2)$

O7-Co2-N4

\subsection{7(4)}

$1.955(4)$

2.065(4)

$94.35(15)$

$165.78(17)$

84.99(15)

103.37(15)

85.79(15)

$\mathrm{Cu} 1-\mathrm{O} 1$
$\mathrm{Cu} 1-\mathrm{O} 2$

O2-Cu1-N1
O2-Cu1-N3
N1-Cu1-N3
N2-Cu1-O1
N3-Cu1-O1

2.485(4)

$1.945(3)$

97.12(16)

170.12(14)

$85.14(16)$

$83.39(15)$

86.37(14)

$\begin{array}{lll}1.950(4) & \mathrm{Cu} 2-\mathrm{N} 4 & 1.980(4) \\ 2.053(4) & \mathrm{Cu} 2-\mathrm{N} 5 & 2.062(4) \\ 1.964(4) & \mathrm{Cu} 2-\mathrm{N} 6 & 1.970(4) \\ 1.940(3) & \mathrm{Cu} 2-\mathrm{O} 3 & 1.942(3) \\ & \mathrm{Cu} 2-\mathrm{O} 5 & 2.361(4)\end{array}$

98.27(17)

163.54(18)

85.03(17)

94.09(16)

169.15(16)

84.83(16)

$92.82(16)$

$85.50(15)$
O3-Cu2-N4

O3-Cu2-N5

N4-Cu2-N5

N6-Cu2-O5

$\mathrm{N} 5-\mathrm{Cu} 2-\mathrm{O} 5$

O3-Cu2-N6

N6-Cu2-N4

N6-Cu2-N5
96.47(16)

169.19(16)

84.23(16)

90.01(16)

97.99(15)

96.36(17)

166.60(18)

83.90(17)

$\begin{array}{clll}\text { Co3-O9 } & 2.106(5) & \text { Co4-O13 } & 2.093(5) \\ \text { Co3-O11 } & 2.126(5) & \text { Co4-O15 } & 2.073(6) \\ \text { Co3-O12 } & 2.123(5) & \text { Co4-O16 } & 2.178(5) \\ \text { Co3-N7 } & 2.242(6) & \text { Co4-N10 } & 2.271(6) \\ \text { Co3-N8 } & 2.140(7) & \text { Co4-N11 } & 2.103(7) \\ \text { Co3-N9 } & 2.118(6) & \text { Co4-N12 } & 2.134(7)\end{array}$

O9-Co3-N9

N9-Co3-O12

N9-Co3-O11

O11-Co3-N8

N9-Co3-N7

O11-Co3-N7

O9-Co3-N8

O12-Co3-N8

O9-Co3-N7

O12-Co3-N7

N8-Co3-N7

O9-Co3-O12

O9-Co3-O11

O12-Co3-O11

N9-Co3-N8

$174.6(2)$

87.7(2)

$92.1(2)$

$90.4(2)$

78.4(2)

162.9(2)

84.1(2)

$172.5(2)$

98.6(2)

106.3(2)

$77.4(2)$

$88.8(2)$

91.9(2)

$87.3(2)$

99.5(2)

O15-Co4-O13

88.1(2)

172.2(2)

83.0(2)

87.1(3)

93.3(3)

107.9(2)

$77.6(3)$

$162.0(2)$

88.5(3)

$170.7(2)$

$100.6(3)$

93.6(2)

90.9(3)

$\begin{array}{ll}\mathrm{O} 13-\mathrm{Co} 4-\mathrm{N} 10 & 96.8(2) \\ \mathrm{N} 12-\mathrm{Co} 4-\mathrm{N} 10 & 75.8(2)\end{array}$

$\begin{array}{ll}\mathrm{O} 13-\mathrm{Co} 4-\mathrm{N} 10 & 96.8(2) \\ \mathrm{N} 12-\mathrm{Co} 4-\mathrm{N} 10 & 75.8(2)\end{array}$ 
$3435,1610,1586,1377,1352,1121,1108,1091,777$, 624.

\subsection{Single crystal X-ray data collection and refinement}

From a batch of crystals of each compound that was transferred from mother liquor to mineral oil for manipulation and selection, a single crystal was placed inside a nylon loop on a goniometer head. Initial crystal evaluation and data collection were performed on a Kappa APEX II diffractometer equipped with a CCD detector (with the crystal-to-detector distance fixed at $60 \mathrm{~mm}$ ) and sealed-tube monochromated $\mathrm{MoK} \alpha$ radiation and interfaced to a PC that controlled the crystal centering, unit cell determination, refinement of the cell parameters and data collection through the program APEX2. ${ }^{12}$ By using the program SAINT ${ }^{12}$ for the integration of the data, reflection profiles were fitted, and values of $\mathrm{F}^{2}$ and $\sigma\left(\mathrm{F}^{2}\right)$ for each reflection were obtained. Data were also corrected for Lorentz and polarization effects. The subroutine $\mathrm{XPREP}^{12}$ was used for the processing of data that included determination of space group, application of an absorption correction (SADABS), ${ }^{12}$ merging of data, and generation of files necessary for solution and refinement. The crystal structures were solved and refined using SHELX 97. ${ }^{13}$ In each case, the space group was chosen based on systematic absences and confirmed by the successful refinement of the structure. Positions of most of the non-hydrogen atoms were obtained from a direct method solution. Several fullmatrix least-squares/difference Fourier cycles were performed, locating the remainder of the non-hydrogen atoms. All non-hydrogen atoms were refined with anisotropic displacement parameters. In order to obtain reasonable thermal parameters compared to other atoms, the lowest residual factors and optimum goodness of fit with convergence of refinement, occupancy factors of the oxygen atoms in the disordered perchlorate anions were adjusted accordingly. All hydrogen atoms of 1-3 except those for lattice water molecules $\mathrm{O} 37$ and $\mathrm{O} 15$ in $\mathbf{1}$ and $\mathbf{3}$, respectively, were placed in ideal positions and refined as riding atoms with individual isotropic displacement parameters. In the final difference Fourier map of 1, the largest residual peak of $1.401 \mathrm{e} / \AA^{3}$ located close to one of the perchlorate ions has been found to be insignificant while in those of $\mathbf{2}$ and $\mathbf{3}$ there was no significant peaks $>1 \mathrm{e} / \AA^{3}$. Crystallographic parameters and basic information pertaining to data collection and structure refinement for all compounds are summarized in table 1. All figures were drawn using MERCURY V $3.0^{14}$ and hydrogen bonding parameters were generated using PLATON. ${ }^{15}$ The final positional and thermal parameters of the non-hydrogen atoms for all structures are listed in the CIF files.

\section{Results and Discussion}

\subsection{Synthesis}

Supramolecular assemblies of 1-3 were prepared from the one pot self-assembly reaction of the metal salt, bpta and the respective sodium salt of the acid (scheme 2). In case of $\mathbf{1}$ and $\mathbf{3}$, the desired product was obtained from the filtrate utilizing the process to remove free $\mathrm{NaClO}_{4}$ with slight excess of $\mathrm{KCl}$ in dry methanol. On the other hand, a blue solid of $\mathbf{2}$ was obtained directly under the same reaction conditions. It should be noted here that the combination of $\mathrm{Cu}$ (II) and adc linker did not allow the isolation of a product similar to $\mathbf{1}$; in fact, there are only a few adc complexes reported in the literature where any ancillary ligand is used. ${ }^{16,17}$

\subsection{Spectroscopic data}

The IR spectra of $\mathbf{1 , 2}$ and $\mathbf{3}$ were recorded in the solid state as $\mathrm{KBr}$ pellets. The peaks at $3404 \mathrm{~cm}^{-1}$ (1), 3438 $\mathrm{cm}^{-1}$ (2) and $3434 \mathrm{~cm}^{-1}$ (3) correspond to the $\mathrm{O}-\mathrm{H}$ stretching frequencies of water molecules. The asymmetric and symmetric stretching frequencies for the carboxylate group appears at 1567 and $1345 \mathrm{~cm}^{-1}$ (1), 1563 and $1380 \mathrm{~cm}^{-1}$ (2) and 1586 and $1377 \mathrm{~cm}^{-1}$ (3), respectively. A difference of 183 to $222 \mathrm{~cm}^{-1}$ between the two stretching frequencies corresponds to the monodentate binding mode of the carboxylate. The peaks at 1096 and $621 \mathrm{~cm}^{-1}$ (1) and 1077 and $619 \mathrm{~cm}^{-1}(\mathbf{2})$ are due to the anionic perchlorate. In case of $\mathbf{3}$, the peaks at $1121,1108,1091$ and $623 \mathrm{~cm}^{-1}$ can be attributed to the anionic and coordinated perchlorates present in it.

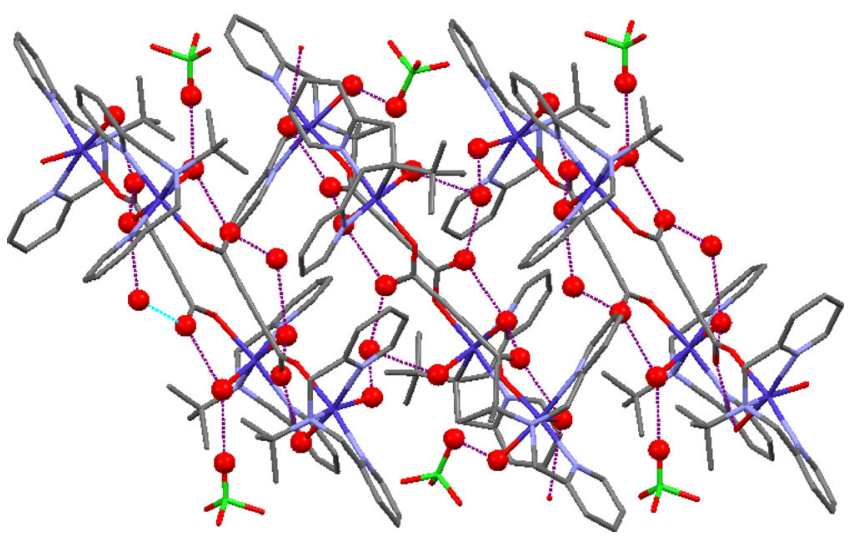

Figure 2. A perspective view of the 3D supramolecular assembly in $\mathbf{1}$ (hanging contacts are deleted for clarity). 
Other peaks with a shift by few wave numbers are due to the bpta ligand which is common in all.

\subsection{Description of the structures}

Single crystals of all three compounds were grown by slow evaporation of the solution in a mixture of methanol and water. 3.3a $\quad\left[\mathrm{Co}_{2}(\mathrm{bpta})_{2}(\mathrm{adc})\left(\mathrm{H}_{2} \mathrm{O}\right)_{4}\right]\left(\mathrm{ClO}_{4}\right)_{2} \cdot 2 \mathrm{H}_{2} \mathrm{O}(\mathrm{I}): \quad$ It is a dinuclear cobalt(II) complex that crystallizes in the monoclinic $P 2_{1} / c$ space group. There are two independent molecules in the asymmetric unit. Each hexacoordinated $\mathrm{Co}$ (II) center is surrounded by three nitrogens of the bpta ligand, two coordinated water molecules and one oxygen of the adc (figure 1). The carboxylate binds to the $\mathrm{Co}$ (II) centers in a bis(monodentate) synsyn fashion which is different from those found in the

Table 3. Hydrogen bonding parameters for $\mathbf{1 , 2}$ and 3 . $^{\mathrm{a}}$

\begin{tabular}{|c|c|c|c|c|c|}
\hline $\mathrm{D}-\mathrm{H} \ldots \mathrm{A}$ & $\mathrm{r}(\mathrm{D}-\mathrm{H}), \AA$ & r (H...A), $\AA$ & r (D...A $), \AA$ & $<\mathrm{D}-\mathrm{H} \ldots\left(^{\circ}\right)$ & Symmetry \\
\hline \multicolumn{6}{|l|}{1} \\
\hline O3 - H3А...O2 & 0.89 & 1.93 & $2.646(10)$ & 137 & \\
\hline $\mathrm{O} 4$-H4A...O32 & 0.87 & 2.36 & $3.160(19)$ & 153 & $\mathrm{x}, 1 / 2-\mathrm{y},-1 / 2+\mathrm{z}$ \\
\hline O4 -H4B...O21 & 0.87 & 2.21 & $3.068(14)$ & 168 & $1-\mathrm{x}, 1-\mathrm{y},-\mathrm{z}$ \\
\hline O7 一H7A...O30 & 0.85 & 2.28 & $3.086(17)$ & 158 & $2-\mathrm{x},-1 / 2+\mathrm{y}, 1 / 2-\mathrm{z}$ \\
\hline O7 —H7B...O35 & 0.85 & 2.21 & $2.775(8)$ & 124 & $1-\mathrm{x},-1 / 2+\mathrm{y}, 1 / 2-\mathrm{z}$ \\
\hline O8 —H8A...O2 & 0.86 & 1.87 & $2.702(9)$ & 163 & $2-\mathrm{x},-\mathrm{y},-\mathrm{z}$ \\
\hline O8 —H8B...O6 & 0.86 & 1.8 & $2.596(8)$ & 153 & \\
\hline O11 —H11A...O14 & 0.87 & 1.89 & $2.732(7)$ & 164 & $1-\mathrm{x}, 1-\mathrm{y},-\mathrm{z}$ \\
\hline O11 - H11B...O38 & 0.87 & 1.81 & $2.673(8)$ & 174 & \\
\hline $\mathrm{O} 12-\mathrm{H} 12 \mathrm{~A} \ldots \mathrm{O} 28$ & 0.85 & 2.28 & $2.932(15)$ & 133 & $1-\mathrm{x},-1 / 2+\mathrm{y}, 1 / 2-\mathrm{z}$ \\
\hline $\mathrm{O} 15-\mathrm{H} 15 \mathrm{~B} \ldots \mathrm{O} 36$ & 0.86 & 1.94 & $2.727(10)$ & 153 & $\mathrm{x}, 1 / 2-\mathrm{y},-1 / 2+\mathrm{z}$ \\
\hline O16 - H16А...O35 & 0.85 & 2.18 & $2.869(8)$ & 138 & $\mathrm{x}, 1 / 2-\mathrm{y},-1 / 2+\mathrm{z}$ \\
\hline O35 —H35D...O6 & 0.85 & 1.82 & $2.668(8)$ & 176 & \\
\hline О35 —Н35Е...О11 & 0.85 & 2.26 & $3.092(7)$ & 165 & $1-\mathrm{x}, 1 / 2+\mathrm{y}, 1 / 2-\mathrm{z}$ \\
\hline О36 - Н36Е...О25 & 0.85 & 2.55 & $3.367(18)$ & 162 & \\
\hline $\mathrm{O} 38-\mathrm{H} 38 \mathrm{C} \ldots \mathrm{O} 10$ & 0.85 & 1.9 & $2.681(9)$ & 153 & $1-\mathrm{x}, 1-\mathrm{y},-\mathrm{z}$ \\
\hline O38 —H38D...O2 & 0.85 & 2.36 & $3.150(10)$ & 156 & \\
\hline C1 —H1A...O18 & 0.97 & 2.6 & $3.558(13)$ & 172 & \\
\hline $\mathrm{C} 1-\mathrm{H} 1 \mathrm{~B} \ldots \mathrm{O} 21$ & 0.97 & 2.29 & $3.105(11)$ & 142 & $1-\mathrm{x}, 1-\mathrm{y},-\mathrm{z}$ \\
\hline C5 - H5...O19 & 0.93 & 2.6 & $3.368(12)$ & 141 & $1-\mathrm{x}, 1-\mathrm{y},-\mathrm{z}$ \\
\hline C16-H16E...O1 & 0.96 & 2.51 & $3.355(10)$ & 147 & \\
\hline C17 一H17А...O1 & 0.96 & 2.51 & $3.359(9)$ & 147 & \\
\hline С27 —H27А...O17 & 0.97 & 2.49 & $3.284(13)$ & 139 & $2-x,-1 / 2+y, 1 / 2-z$ \\
\hline С28 - H28А...O30 & 0.97 & 2.56 & $3.276(18)$ & 130 & $2-\mathrm{x},-1 / 2+\mathrm{y}, 1 / 2-\mathrm{z}$ \\
\hline C33 - H33...O8 & 0.93 & 2.56 & $3.098(9)$ & 117 & \\
\hline С36 -H36А...О5 & 0.96 & 2.47 & $3.346(11)$ & 151 & \\
\hline C44 - Н44A...O23 & 0.97 & 2.55 & $3.338(11)$ & 139 & \\
\hline C49 - H49...O33 & 0.93 & 2.39 & $3.29(2)$ & 163 & \\
\hline С53 - Н53А...О15 & 0.96 & 2.5 & $3.387(11)$ & 153 & \\
\hline С64 一H64А...O23 & 0.97 & 2.52 & $3.357(11)$ & 145 & $1-\mathrm{x},-1 / 2+\mathrm{y}, 1 / 2-\mathrm{z}$ \\
\hline С64 -H64В...O24A & 0.97 & 2.55 & $3.21(2)$ & 125 & $1-\mathrm{x},-1 / 2+\mathrm{y}, 1 / 2-\mathrm{z}$ \\
\hline С68 —H68. . . O33 & 0.93 & 2.41 & $3.27(3)$ & 153 & $2-\mathrm{x},-1 / 2+\mathrm{y}, 1 / 2-\mathrm{z}$ \\
\hline $\begin{array}{l}\mathrm{C} 72-\mathrm{H} 72 \mathrm{~A} \ldots \mathrm{O} 12 \\
\mathbf{2}\end{array}$ & 0.96 & 2.55 & $3.413(10)$ & 150 & \\
\hline $\mathrm{O} 1-\mathrm{H} 1 \mathrm{~A} \ldots \mathrm{O} 3$ & 0.85 & 1.97 & $2.750(5)$ & 149 & $\mathrm{x},-\mathrm{y},-1 / 2+\mathrm{z}$ \\
\hline $\mathrm{O} 1-\mathrm{H} 1 \mathrm{~B} . . . \mathrm{O} 6$ & 0.86 & 2.35 & $3.112(15)$ & 146 & \\
\hline O1 -H1B...O7 & 0.86 & 2.28 & $3.114(10)$ & 163 & \\
\hline $\begin{array}{l}\mathrm{C} 13-\mathrm{H} 13 \ldots \mathrm{O} 6 \\
3\end{array}$ & 0.93 & 2.33 & $3.227(15)$ & 162 & $1 / 2-x, 1 / 2-y, 1-z$ \\
\hline $\begin{array}{l}\text { O } \\
\mathrm{O} 5-\mathrm{H} 5 \mathrm{~A} . . . \mathrm{O} 14\end{array}$ & 0.87 & 1.91 & 2.747 & 162 & $1 / 2+\mathrm{x}, 1 / 2-\mathrm{y},-1 / 2+\mathrm{z}$ \\
\hline $\mathrm{O} 14-\mathrm{H} 14 \mathrm{D} \ldots \mathrm{O} 15$ & 0.85 & 2.32 & $2.954(10)$ & 131 & \\
\hline O16 - Н16А...O4 & 0.85 & 2.31 & $3.055(13)$ & 147 & $-1+\mathrm{x}, \mathrm{y}, \mathrm{z}$ \\
\hline $\mathrm{C} 24 \ldots \mathrm{H} 24 \ldots \mathrm{O} 6$ & 0.93 & 2.51 & $3.362(9)$ & 152 & \\
\hline
\end{tabular}

${ }^{a}$ Values in parenthesis are estimated standard deviations in the last significant digits. 
$\mathrm{Mn}(\mathrm{II})$-adc complex of the same ligand. ${ }^{16}$ The $\mathrm{Co}-\mathrm{O}_{\text {water }}$ distances vary from $2.073 \AA$ to $2.178 \AA$ whereas Co- $\mathrm{O}_{\text {adc }}$ distances vary from $2.093 \AA$ to $2.119 \AA$. All other selected bond distances and angles are listed in table 2.

Two discrete dinuclear units are hydrogen bonded with each other via coordinated and lattice water molecules to form a supramolecular assembly as shown in figure 2. All the hydrogen bonding parameters are listed in table 3 . The coordinated water molecule $\mathrm{O} 4$ of one discrete dinuclear unit is hydrogen bonded to the $\mathrm{O} 32$ (perchlorate oxygen atom), $\mathrm{O} 8$ is hydrogen bonded to $\mathrm{O} 2$ (uncoordinated oxygen atom of adc of the next same subunit), $\mathrm{O} 8$ is intramolecularly hydrogen bonded to $\mathrm{O6}$ (uncoordinated oxygen atom of adc of same subunit), $\mathrm{O} 7$ is hydrogen bonded to $\mathrm{O} 35$ (lattice water molecule) which is further hydrogen bonded to $\mathrm{O} 16$ (coordinated water molecule on second subunit) connecting the two subunits. Similar hydrogen bonding pattern is found for the second dinuclear unit. Thus, these two subunits are connected with each other via a network of hydrogen bonding which can be clearly seen in figure 3 . In another view shown in figure 4 the two layers formed by hydrogen bonding of two subunits are arranged in a spiral manner and it forms a channel in which perchlorate anions are sitting; in other words, a perchlorate channel is formed between the two hydrogen bonded units.

3.3b $\quad\left[\mathrm{Cu}_{2}(\text { bpta })_{2}(\mathrm{fum})\left(\mathrm{H}_{2} \mathrm{O}\right)_{2}\right]\left(\mathrm{ClO}_{4}\right)_{2} \quad(2):$ It is a discrete dinuclear $\mathrm{Cu}$ (II) complex that crystallizes in the $C 2 / c$ space group. Due to the presence of a 2-fold axis, the five coordinated $\mathrm{Cu}$ (II) centers are crystallographically equivalent. The fumarate binds in a bis(monodentate) syn-anti mode. The $\mathrm{Cu}-\mathrm{O}_{\text {water }}$

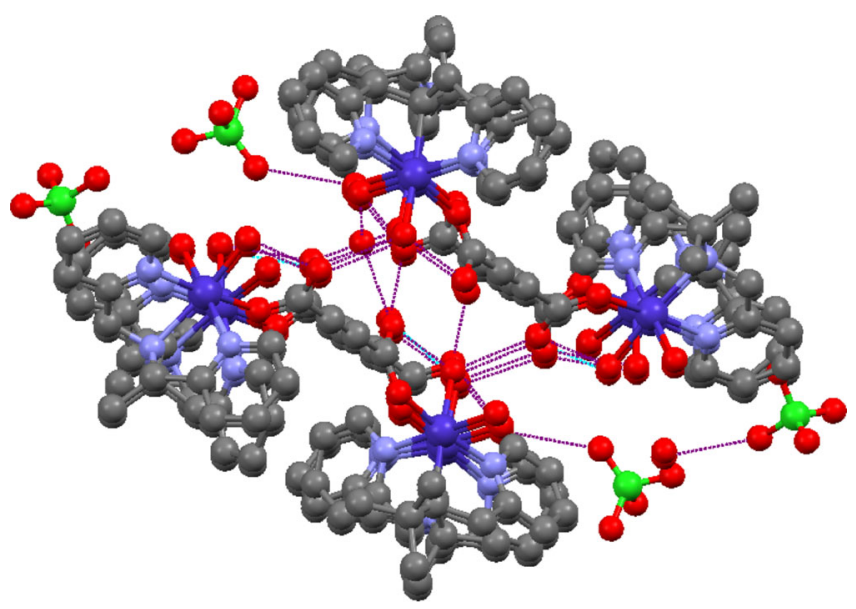

Figure 3. Hydrogen bonded network in $\mathbf{1}$ along the ' $a$ ' axis.

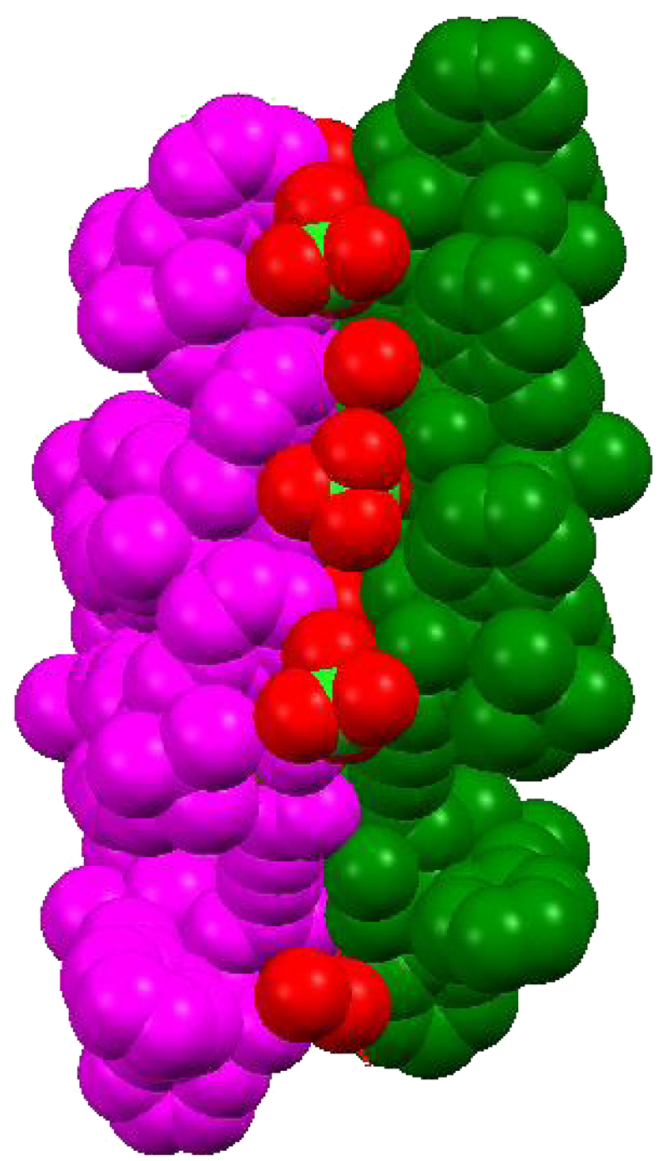

Figure 4. A schematic view of the perchlorate channel between the hydrogen bonded network of two independent units in $\mathbf{1 .}$

distance is $2.485 \AA$ whereas $\mathrm{Cu}-\mathrm{O}_{\text {fum }}$ distance is 1.946 $\AA$. In figure 5 , the schematic drawing of the dimetal synthon in $\mathbf{2}$ shows trans orientation of the coordinated water molecules that are involved in the formation of a supramolecular assembly (vide infra). Similar types of complexes are reported with 1,10-phenanthroline but with no coordinated water molecule on the $\mathrm{Cu}$ (II) center. ${ }^{18}$ The selected bond distances and angles are listed in table 2.

Due to the trans orientation of the coordinated water molecules on the $\mathrm{Cu}$ (II) centers, $\mathrm{O} 1$ (coordinated

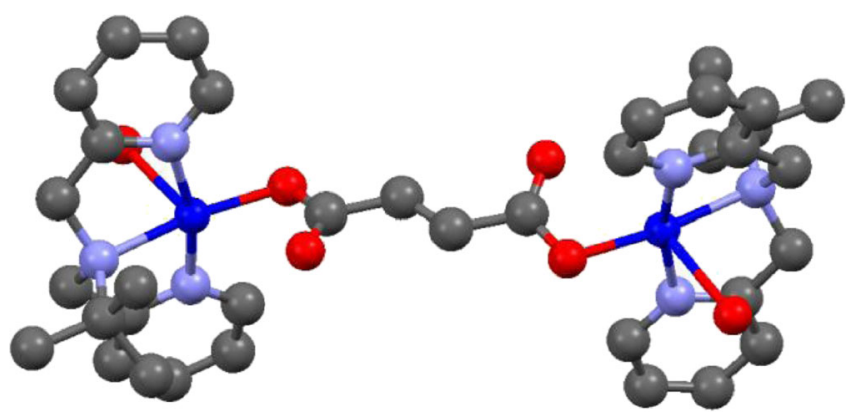

Figure 5. Structure of the dimetal subunit in 2 . 


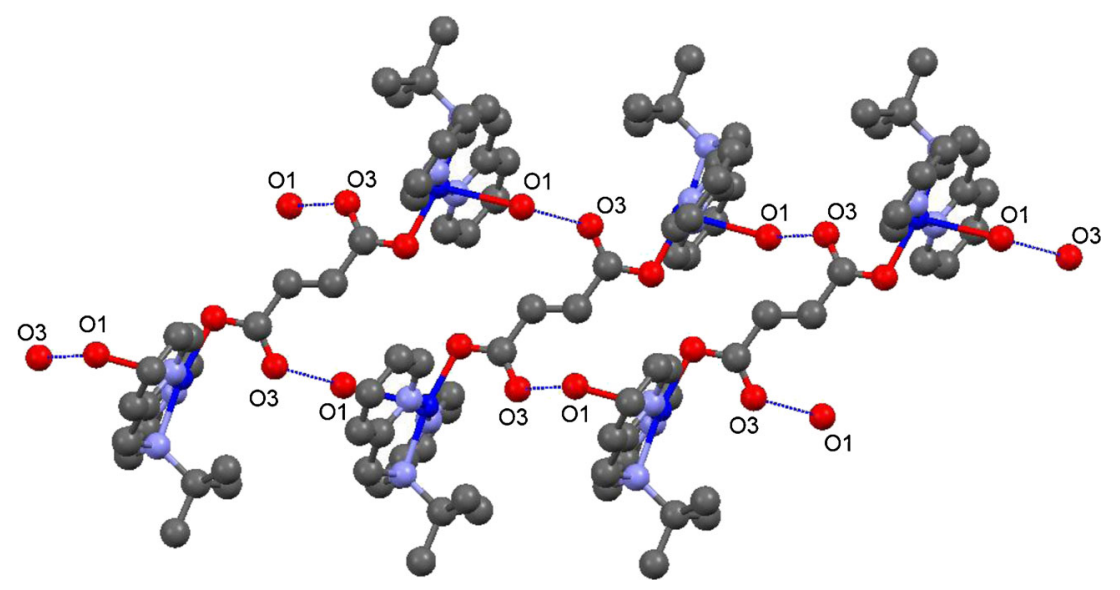

Figure 6. A ladder-shaped supramolecular assembly in $\mathbf{2}$ (perchlorates are not included for clarity).

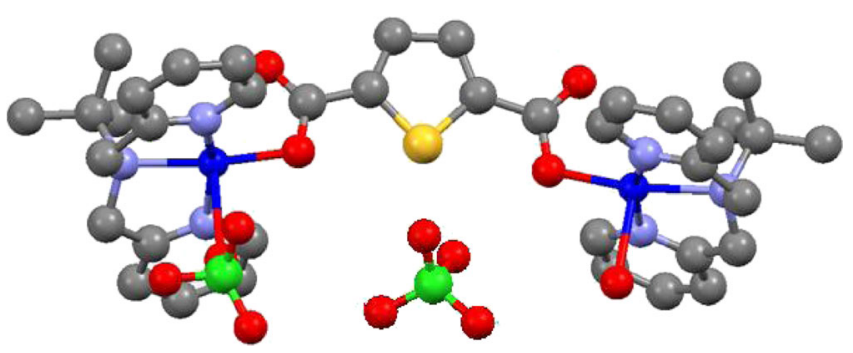

Figure 7. A view of the dimetal subunit (along with the free perchlorate ion) in $\mathbf{3}$.

water molecule) is hydrogen bonded to the uncoordinated oxygen $\mathrm{O} 3$ of the fumarate of next dinuclear unit forming a ladder shaped supramolecular assembly shown in figure $6(\mathrm{O} 1 \ldots \mathrm{O} 3$ distance: $2.750 \AA$ and $\mathrm{O} 1-\mathrm{H} 1 \mathrm{~A} \cdots \mathrm{O} 3$ angle: $\left.149^{\circ}\right)$. The coordinated water molecule $\mathrm{O} 1$ is also hydrogen bonded to one of the perchlorate anions which is not shown in the figure for clarity. All hydrogen bonding parameters are listed in table 3.
$3.3 \mathrm{c} \quad\left[\mathrm{Cu}_{2}(\mathrm{bpta})_{2}(\mathrm{tdc})\left(\mathrm{H}_{2} \mathrm{O}\right)\left(\mathrm{ClO}_{4}\right)\right]\left(\mathrm{ClO}_{4}\right) \cdot 3 \mathrm{H}_{2} \mathrm{O}(3)$ : The $\mathrm{Cu}$ (II) centers in $\mathbf{3}$ are pentacoordinated and inequivalent. One $\mathrm{Cu}$ (II) center is surrounded by three nitrogens of the ligand, one coordinated water molecule and one oxygen of tdc while the other does not have coordinated water molecule and its fifth site is occupied by the perchlorate oxygen. The tdc binds in a bis(monodentate) syn-syn mode between the two $\mathrm{Cu}$ (II) centers as shown in figure 7 , similar to the ones with 1,10-phenanthroline and imidazole ligands reported in the literature. ${ }^{19-21}$ The selected bond distances and angles are listed in table 2.

The dinuclear subunit forms a polymeric chain structure in one direction due to hydrogen bonding of the coordinated perchlorate oxygen $(\mathrm{O} 10)$ with uncoordinated oxygen atom of tdc $(\mathrm{O} 2)$ via a lattice water molecule (O15) (figure 8), which is further hydrogen bonded to another lattice water molecule O14. In the next layer, the dinuclear subunits are hydrogen bonded via the third lattice water molecule $(\mathrm{O} 16)$ and the coordinated water molecule (O5) and uncoordinated

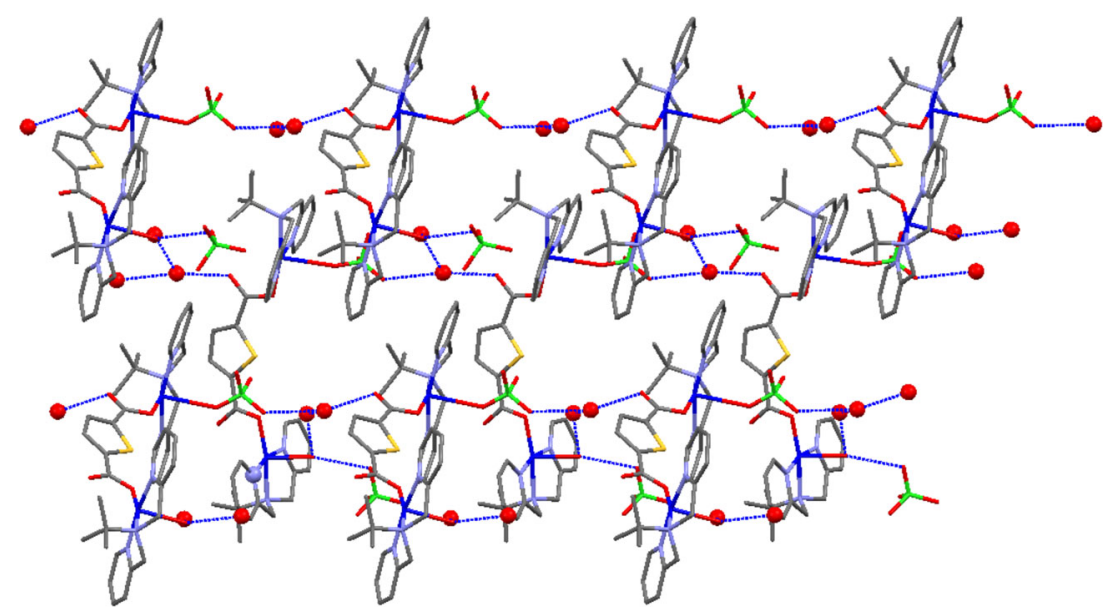

Figure 8. A perspective view of the 3D supramolecular assembly in $\mathbf{3}$ (hanging contacts are deleted for clarity). 
carboxylate oxygen atom (O4). These alternate layers are repeated to form the 3D supramolecular assembly in $\mathbf{3}$. The hydrogen bonding parameters for $\mathbf{3}$ are listed in table 3 .

\section{Conclusion}

We have reported structural diversities in the supramolecular assemblies with varying degrees of coordinated water molecules per dimetal subunits of $\mathrm{Co}$ (II) or $\mathrm{Cu}$ (II) (four for $\mathbf{1}$, two for $\mathbf{2}$ and one for $\mathbf{3}$, respectively) comprised of a flexible tridentate ligand and different dicarboxylate linkers. It is clear that these carboxylates play an important role in determining the coordination architectures with respect to their size, conformation and properties. Unlike $\mathbf{1}$ and $\mathbf{3}$, there is no lattice water molecule in $\mathbf{2}$. However, the role played by lattice water molecules in $\mathbf{1}$ and $\mathbf{3}$ in the construction of such assemblies is distinctly different. The formation of a ladder shaped supramolecular assembly in $\mathbf{2}$ is the result of the trans orientation of the coordinated water molecules in the dimetal subunit. Based on the results presented here, further work continues in our laboratory to understand the effect of the change in the ancillary ligands and other metal centres.

\section{Supplementary Information}

Crystallographic data of the structures $\mathbf{1 - 3}$ in CIF format (CCDC 1000552-1000554, respectively). Copies of the data can be obtained, free of charge, on application to CCDC, 12 Union Road, Cambridge CB2 1EZ, UK, (fax: +44-(0)1223-336033 or e-mail: deposit@ccdc.cam.ac.uk)

\section{Acknowledgements}

Funding for this work was provided by IISER, Mohali. S. K. is grateful to CSIR, India for research fellowship. The use of X-ray and NMR facilities at IISER, Mohali, and CIL, NIPER, Mohali for CHN analysis are gratefully acknowledged. We thank one of the referees for helpful suggestions.

\section{References}

1. (a) Lehn J-M 1995 In Supramolecular Chemistry: Concepts and Perspectives (New York: VCH); (b) Steed J W, Atwood J L 2009 In Supramolecular Chemistry (UK: John Wiley)
2. Dmitriev A, Lin N, Barth J V and Kern K 2003 Angew. Chem. Int. Ed. 422670

3. (a) Kitagawa S, Kitaura R and Noro S 2004 Angew. Chem. Int. Ed. 43 2334; (b) Tranchemontagne D J, Mendoza-Cortés J L, O'Keeffe M, Yaghi O M 2009 Chem. Soc. Rev. 38 1257; (c) Kurmoo M 2009 Chem. Soc. Rev. 38 1353; (c) O'Keeffe M, Yaghi O M 2012 Chem. Rev. 112 675; (d) Suh M K, Park H J, Prasad T K and Lim D-W 2012 Chem. Rev. 112 782; (e) Li J-R, Sculley J and Zhou H-C 2012 Chem. Rev. 112 869; (f) Kreno L F, Leong K, Farha O K, Allendorf M, Van Duyne R P and Hupp J T 2012 Chem. Rev. 112 1105; (g) Cui Y, Yue Y, Qian G and Chen G 2012 Chem. Rev. 1121126

4. (a) Desiraju G R 2003 In Crystal Design: Structure and Functions (Perspectives in Supramolecular Chemistry) (England: John Wiley); (b) Desiraju G R, Vittal J J and Ramanan A 2011 In Crystal Engineering. A Text Book (Singapore: World Scientific)

5. Burrows A D, Chan C W, Chowdhry M M, McGrady J E and Mingos D M P 1995 Chem. Soc. Rev. 24329

6. Brammer L 2003 In Perspective in Supramolecular Chemistry - Crystal Design: Structure and Function G. R. Desiraju (Ed.) (England: Wiley) Vol. 7, pp 1-75

7. Beatty A M 2001 CrystEngComm 3243

8. Aakeroy C B and Beatty A M 2001 Aust. J. Chem. 54 409

9. Desiraju G R 2000 J. Chem. Soc., Dalton Trans. 3745

10. Subramanian S and Zaworotko M J 1994 Coord. Chem. Rev. 137357

11. Mok H J, Davis J A, Pal S, Mandal S K and Armstrong W H 1997 Inorg. Chim. Acta 263385

12. APEX2, SADABS and SAINT 2008 Bruker AXS inc: Madison, WI, USA

13. Sheldrick G M 2008 Acta Crystallogr., Sect. A: Found. Crystallogr. 64112

14. Macrae C F, Bruno I J, Chisholm J A, Edginton P R, McCabe P, Pidocck E, Rodriguez-Monge L, Taylor T, Van de Streek J and Wood P A 2008 J. Appl. Crystallogr. 41266

15. Spek A L 1999 PLATON, Version 1.62, University of Utrecht

16. (a) Khullar S and Mandal S K 2012 Cryst. Growth Des. 125329 and references therein; (b) Khullar S and Mandal S K 2013 Cryst. Growth Des. 13 3116; (c) Khullar S, Gupta V and Mandal S K 2014 Cryst Eng Comm 165705

17. (a) Skoulika S, Dallas P, Siskos M G, Deligiannakis Y and Michaelides A 2003 Chem. Mater. 15 4576; (b) Stein I and Ruschewitz U 2009 Z. Naturforsch., B: J. Chem. Sci. 64 1093; (c) Wang H-Y, Gao S, Huo L-H and Zhao J-G 2007 Acta Crystallogr., Sect. E: Struct. Rep. Online $63 \mathrm{~m} 2995$

18. Wang Y Y, Wang X, Shi Q Z and Gao Y C 2002 Trans. Metal Chem. 27481

19. (a) Chen B L Mok K F, Ng S C, Feng Y L and Liu S X 1998 Polyhedron 17 4237; (b) Chen B L, Mok K F, Ng S C and Drew M G B 1999 Polyhedron 181211

20. Xiao H P 2005 Acta Crystallogr. E61 m2592

21. Yeşilel O Z, İlker I, Büyükgüngor O 2009 Polyhedron 283010 